\title{
Adaptive skill of Schizothorax sp. of river Alaknanda under long term pressure of urbanization and anthropogenic activities in Garhwal Himalaya
}

\author{
Thapliyal M. ${ }^{1}$, Bahuguna S. N. ${ }^{2}$ and Thapliyal A. ${ }^{3}$
}

Received: 29.12.2018

Revised: 08.04.2019

Accepted: 21.05.2019

\begin{abstract}
It is universally accepted that humans are having a major impact on every aspect of earth's ecological habitats because humans are engaged in urbanization and anthropogenic activity. All the major watershed areas of Garhwal Himalayan region (Alaknanda, Bhagarathi/Ganges and Yamuna) have witnessed urbanization and anthropogenic activity. One hydroelectric power project (330 MW) is located on river Alaknanda at Srinagar Garhwal in Garhwal Himalaya. The project started during the mid1990s by GVK group and completed around 2014. A long term study on fecundity of Schizothorax sp. at Srinagar Garhwal was carried out between the years 1996 to 1998. This study was compared to other recent studies on same species at same location between the years 2016-19. This period covers the entire timeline of construction phase to commissioning phase of this hydroelectric power project. Various parameters with reference to breeding biology and fecundity were measured from Schizothorax sp. Mature specimens ranging in average weight from $384 \mathrm{~g}$ to $1482 \mathrm{~g}$ and average length from $320 \mathrm{~mm}$ to $544 \mathrm{~mm}$ were observed. Weight of ovary in the fish fluctuated from $38 \mathrm{~g}$ to $219 \mathrm{~g}$. Fecundity of samples varied from a minimum to 3009 to a maximum of 13649 to 13840 . The mathematical relationship of fecundity with other variables viz: fish length, fish weight, ovary weight and ovary length, and between fish weight and ovary weight and ovary length was calculated. The computed relationships were found to be highly significant especially between fecundity and fish length $(r=0.940, p<0.01)$, fecundity and fish weight $(r=0.937, p<0.01)$ and fecundity and ovary volume $(r=0.913, p>0.01)$. The values of regression coefficient $(b)$ and correlation coefficient $(r)$ were computed separately. The data when compared to recent data of other authors reveals that Schizothorax sp. have sustained their fecundity due to their unique adaptive skill but have shifted their breeding grounds slightly. This shifting of breeding ground might be due to anthropogenic activity. Further studies would be needed to see if the breeding grounds are also restored.
\end{abstract}

Key words: Fecundity, Gonadosomatic Index, Schizothorax, Sringar Garhwal, Garhwal Himalaya, Hydroelectric Power project

\section{Introduction}

There are three main watersheds in Garhwal Himalayan region of Uttarakhand of India. These are the Alaknanda, Bhagirathi (Ganges) and the Yamuna watershed. Due to their perennial water supply, and keeping in view the tremendous energy demand due to increasing population, several hydroelectric power projects have been either constructed or are under construction in these watersheds. Because of these constructions, the aquatic habitat and aquatic diversity is threatened.

\section{Author's Address}

${ }^{1}$ Department of Zoology, Government Degree College, Raipur, Dehradun.

${ }^{2}$ Department of Zoology and Biotechnology, HNB Garhwal University (Central University), Campus College Srinagar Garhwal, Uttarakhand.

3 Department of Biotechnology/Life Sciences, Graphic Era (Deemed to be University), Dehradun.

E-mail.: madhuthapliyal@gmail.com
Fishes are most abundant species in river and directly connected to us in the form of food (economics) and aesthetic value. Besides they are also the key indicators of ecosystem as they live in specialized niches. Since they are among the key components of biodiversity and indicators of habitat, the study of their reproduction biology and fecundity is important. If the habitat for the fish species is perfect, they will reproduce at specific spawning grounds and if there are issue with the habitat, then they will preferably migrate to suitable grounds. Besides spawning grounds the number of eggs produced by female fish is also a key parameter which is also referred as fecundity. There are several studies documenting fishes in Alaknanda river and Bhagarathi since the 1970s and 80s (Agarwal et al., 1988; Agarwal and Singh, 2009; Bisht and Joshi, 1975; Singh and Sharma 
1995; Thapliyal et al., 2011 and 2012; Sharma and Bargali, 2018). Reproductive biology Schizothorax $s p$. has also been investigated in Kashmir and other locations (Wagle, 2015; Sunder and Subla 2013; Sabha et al., 2017; Roy et al., 2011; Roopam et al., 2009; Qadri et al., 2013; Gandotra et al., 2009; Jan et al., 2014). In our present paper, we documented the fecundity of Schizothorax sp. from 1996 to 1998 and then compared it to studies which were done at the same location.

\section{Materials and Methods}

Study site was located at Srinagar Garhwal in Uttarakhand $\left(30^{\circ} 13^{\prime} 28.83^{\prime \prime} \mathrm{N}\right.$ and $78^{\circ} 47^{\prime} 55.03^{\prime \prime} \mathrm{E}$ (Fig. 1). The sampling site was located 500 meters down-stream from the dam wall just by the bridge (Fig. 2 and Fig 3). The river meanders at this location resulting in some shallow pools that are used as breeding grounds by Schizothorax $s p$. Collection of fully mature female fishes was done

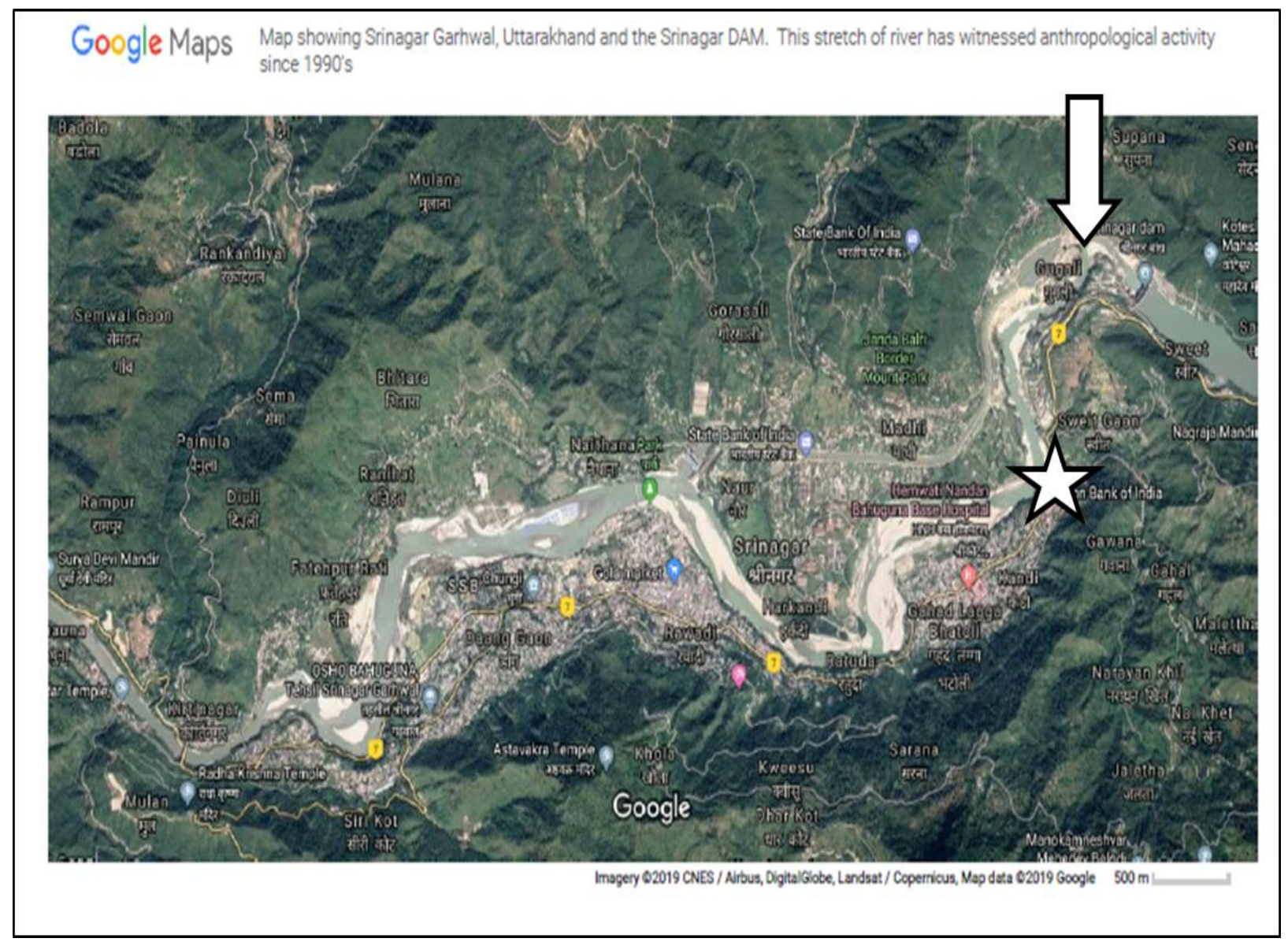

Fig 1. Location of study site. The dam wall is marked by an arrow. The study site is marked as a star. Map has been taken from Google Earth. The area between the arrow and the star was the dumping ground for all the soil / construction material.

during 1996 - 98. A total of 81 fishes were procured from the local fisherman and market having high state of maturity with ripe ovary (transparent, broad and highly vascular and smooth uneven surface due to presence of ripe ova heavily loaded with yolk). The length and weight of each fish was recorded/measured in fresh condition. The ovaries were then dissected out and preserved in
$4 \%$ formalin to impart hardness. After allowing the ovaries to attain some hardness, they were kept out, wiped with blotting sheets for $30 \mathrm{~min}$ so that the ovaries had no moisture. The weight and volume of the preserved ovaries were recorded carefully. The sub-samples from the anterior, middle and posterior regions of both the ovaries were mixed randomly and subject to volumetric (Kandler and 


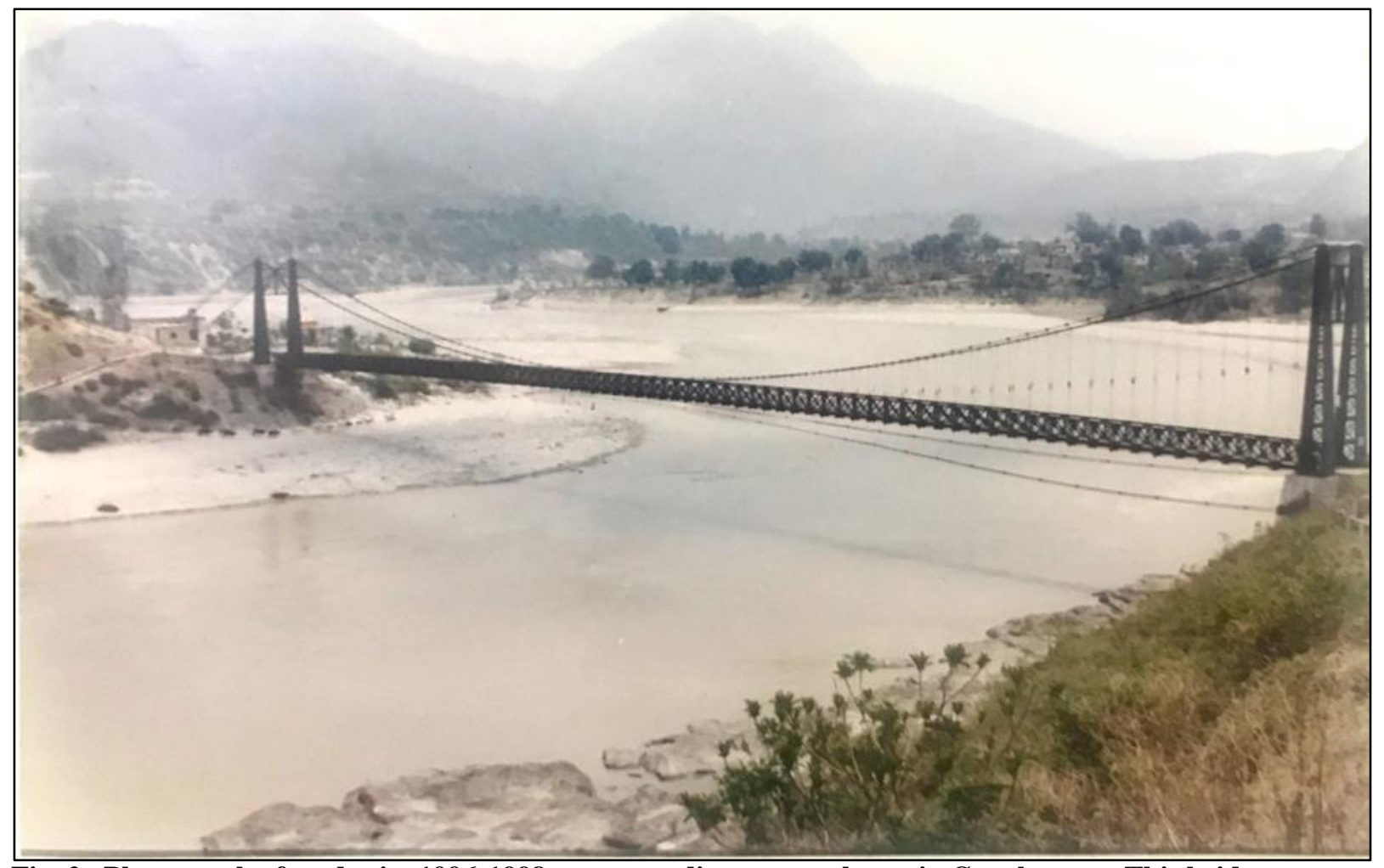

Fig. 2. Photograph of study site 1996-1998 corresponding to star shown in Google map. This bridge was damaged during floods of 2013 and now a new bridge has been constructed at same location (source - Thesis of Dr. Madhu Thapliyal)

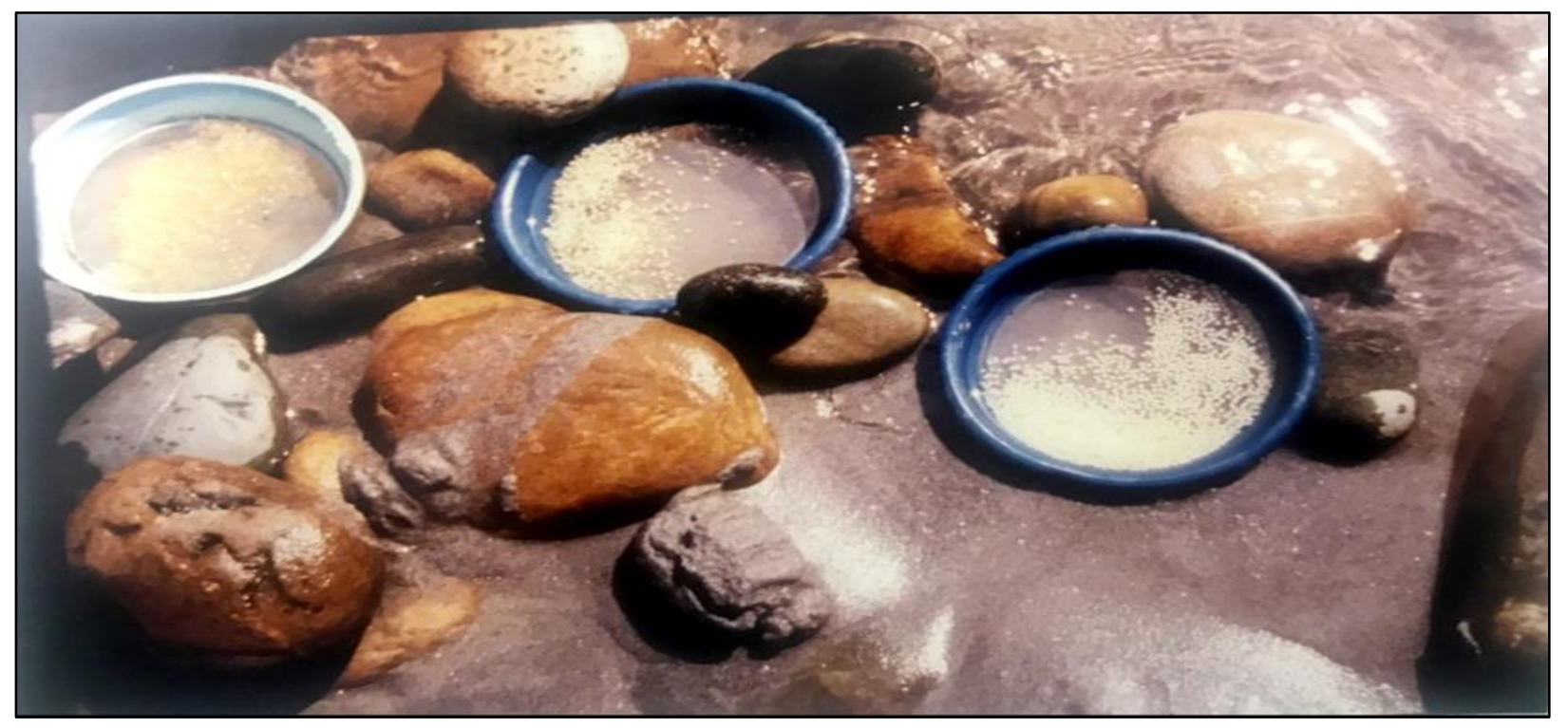

Fig 3. Photograph of eggs at study site during 1996-1998. This site was near the bridge along the curved region of river (source - Thesis of Dr. Madhu Thapliyal). 
pirwitz, 1957) and gravimetric analysis (Simpson, 1959).

a. Volumetric method: A specific volume $(1 \mathrm{ml})$ of the samples was taken and subjected to counting. The final results were computed to determine the number of eggs in the total volume of the ovary. The average of five counts was taken into consideration.

b. Gravimetric method: The preserved and washed eggs were kept on a blotting paper to remove the excess moisture and felt to air dry. The fecundity estimate was obtained by weighing the random samples of 200 eggs five times and fitting the values obtained into the formula:

$$
\text { Fecundity }=\frac{\text { Total weight of the eggs }}{\text { Weight of the sub sample }} \times 100
$$

The mean value of both the methods (volumetric and gravimetric) were recorded as the absolute fecundity. Relative fecundity was determined by the ratio of total number of ova to total weight of fish. The relationship between the fecundity and the fish weight/fish length / ovary volume / ovary weight / ovary length were established by applying the method of least square i.e.

$$
\begin{aligned}
& Y=a+b x \\
& \log Y=\log a+b \log X
\end{aligned}
$$

Where $\mathrm{Y}=$ fecundity, $\mathrm{X}=$ Body measurements such as body length / body weight / ovary volume / ovary, $\mathrm{a}=$ intercept, $\mathrm{b}=$ slope are constants. Analysis of variance ANOVA was carried out on the data to examine the effect of various body parameters on fecundity.

\section{Result and Discussion}

All that data is tabulated in tables (table 1, table 2 and table 3). The results are as follows:

Fecundity and fish length (TL): It was observed that normally the larger fishes had relatively more eggs. For a fish measuring $555 \mathrm{~mm}$, the maximum number of ova was estimated to be 13,862 the minimum was 3,880 for a fish of $350 \mathrm{~mm}$ in total length. The fecundity value and total fish length group has been computed in table 10 . The average fecundity value of different length groups were recorded to range from 3007 to 13,649 in the mean total length of $320.4 \mathrm{~mm}$ to $544.4 \mathrm{~mm}$. The correlation coefficient ' $r$ ' is 0.940 , which indicates that the fecundity was more and directly related to fish length. The relationship between fecundity and fish length can be expressed as:

$\log F=2.9942+2.5709 \log T L \quad(r=0.940)$

Where $\mathrm{F}$ represents fecundity and TL is the total length of fish.

Fecundity and Fish weight (FW): The data related to fish weight and fecundity has been computed in table. The number of ova ranged from 3128 at mean weight of $662 \mathrm{gm}$ to 13,52 at $1833.5 \mathrm{gm}$. The data between log weight and log fecundity may be expressed as:

$\log F=0.8403+1.0323 \log F W(r=0.937)$

Fecundity and ovary volume $(\mathrm{OV})$ : The average egg production corresponding to average ovary volume has been tabulated in table. The maximum ovary volume was recoded to be $175 \mathrm{ml}$ and the fecundity being 13,862 . The relationship may be expressed as:

$\log F=2.2291+0.813 \log O V(r=0.913)$

Fecundity and Ovary Weight (OW): The relationship between ovary weight and fecundity was found to be linear and the relationship is expressed as:

$\log F=2.4545+0.6966 \log$ OW $(r=0,852)$

Fecundity and Ovary Length (OL): For evaluating the relationship of ovary length and average number of eggs was computed - table. It was observed that ovary length ranges from 124 $\mathrm{mm}$ to $268 \mathrm{~mm}$ and total fish length range from 300 to $590 \mathrm{~mm}$. Fecundity increased with ovary length but there seems to be no direct relationship as ' $r$ ' value was 0.568 . The relationship can be expressed as:

$\log F=1.9299+0.7867 \log$ OL $(r=0.5688)$

Ovary Weight (OW) and Fish Length (FL): Weight of ovary in fish is influenced by its size. The relationship between total fish length and ovary weight was found to be fairly close and linear and the ' $r$ ' value was 0.825 . The relationship between length and ovary weight may be expressed as:

$\log$ OW $=-6.5726+3.2145 \log (\mathrm{FL})(\mathrm{r}=0.825)$

Ovary weight and Fish Weight (FW): Relationship between the two can be expressed as: $\log \mathrm{OW}=2.487+0.0082 \log (\mathrm{FW})(\mathrm{r}=0.865)$

Fecundity has been expressed as the total number of eggs produced in one spawning season. The number of eggs in ovary of a fish is of importance in estimating the number of individuals at the start 
Table 1. Relationship between fecundity and various body/ovary parameters.

\begin{tabular}{|c|c|c|c|c|c|c|c|c|c|c|c|}
\hline \multicolumn{2}{|c|}{$\begin{array}{l}\text { Total Fish } \\
\text { Length } \\
(\mathrm{mm})\end{array}$} & \multicolumn{2}{|c|}{$\begin{array}{l}\text { Fish Weight } \\
\text { (g) }\end{array}$} & \multicolumn{2}{|c|}{$\begin{array}{l}\text { Ovary Weight } \\
\text { (g) }\end{array}$} & \multicolumn{2}{|c|}{$\begin{array}{l}\text { Ovary volume } \\
\text { (ml) }\end{array}$} & \multicolumn{2}{|c|}{$\begin{array}{l}\text { Ovary length } \\
(\mathrm{mm})\end{array}$} & \multicolumn{2}{|c|}{ Fecundity } \\
\hline Range & Average & Range & Average & Range & Average & Range & Average & Range & Average & Range & Average \\
\hline $\begin{array}{l}300- \\
350\end{array}$ & 320.4 & $\begin{array}{l}330- \\
430\end{array}$ & 384.5 & $\begin{array}{l}43.9- \\
45\end{array}$ & 38.5 & $\begin{array}{l}37- \\
44.5\end{array}$ & 44.23 & $\begin{array}{l}124- \\
199\end{array}$ & 154 & $\begin{array}{l}2250- \\
3880\end{array}$ & 3007 \\
\hline $\begin{array}{l}351- \\
410\end{array}$ & 386.3 & $\begin{array}{l}432- \\
614\end{array}$ & 483.7 & $\begin{array}{l}43.63- \\
50.8\end{array}$ & 45.70 & $\begin{array}{l}43- \\
48.8\end{array}$ & 44.87 & $\begin{array}{l}195- \\
209\end{array}$ & 195.3 & $\begin{array}{l}4210- \\
5778\end{array}$ & 4925 \\
\hline $\begin{array}{l}411- \\
470\end{array}$ & 490.1 & $\begin{array}{l}620- \\
760\end{array}$ & 765.2 & $\begin{array}{l}52.8- \\
70.1\end{array}$ & 73.08 & $\begin{array}{l}50- \\
110\end{array}$ & 80.84 & $\begin{array}{l}212- \\
230\end{array}$ & 227.4 & $\begin{array}{l}5856- \\
7008\end{array}$ & 5757 \\
\hline $\begin{array}{l}471- \\
530\end{array}$ & 500.1 & $\begin{array}{l}772- \\
1244\end{array}$ & 1043.9 & $\begin{array}{l}75- \\
198\end{array}$ & 153.2 & $\begin{array}{l}112- \\
170\end{array}$ & 143.28 & $\begin{array}{l}232- \\
254\end{array}$ & 244 & $\begin{array}{l}7620- \\
12110\end{array}$ & 8784 \\
\hline $\begin{array}{l}531- \\
590\end{array}$ & 544.4 & $\begin{array}{l}1250- \\
2000\end{array}$ & 1482.2 & $\begin{array}{l}200- \\
228.3\end{array}$ & 219.75 & $\begin{array}{l}170- \\
178\end{array}$ & 175.71 & $\begin{array}{l}255- \\
268\end{array}$ & 260.6 & $\begin{array}{l}13261- \\
13862\end{array}$ & 13649 \\
\hline
\end{tabular}

Table 2. Relationship between fish weight, fecundity and Ovary weight.

\begin{tabular}{|c|c|c|c|c|c|c|c|}
\hline \multicolumn{2}{|l|}{$\begin{array}{l}\text { Fish Weight } \\
\text { (g) }\end{array}$} & \multirow[t]{2}{*}{$\begin{array}{l}\text { No. of fishes } \\
\text { observed }\end{array}$} & \multicolumn{2}{|c|}{ Fecundity } & \multicolumn{2}{|c|}{$\begin{array}{l}\text { Ovary weight } \\
\text { (g) }\end{array}$} & \multirow[t]{2}{*}{$\begin{array}{l}\text { \% of ovary in tota } \\
\text { weight of fish }\end{array}$} \\
\hline Range & Average & & Range & Average & Range & Average & \\
\hline $330-664$ & 662 & 39 & $\begin{array}{l}2250- \\
4006\end{array}$ & 3128 & $\begin{array}{l}45- \\
58.2\end{array}$ & 51.6 & 7.79 \\
\hline $665-998$ & 831.5 & 25 & $\begin{array}{l}4420- \\
8949\end{array}$ & 6584 & $\begin{array}{l}60- \\
189.5\end{array}$ & 124.75 & 15.00 \\
\hline 999-1332 & 1165.5 & 16 & $\begin{array}{l}9924- \\
13766\end{array}$ & 11845 & 194-198 & 196 & 16.81 \\
\hline $1667-2000$ & 1833.5 & 02 & $\begin{array}{l}13840- \\
13862\end{array}$ & 13851 & $\begin{array}{l}200- \\
228.3\end{array}$ & 214.15 & 11.67 \\
\hline
\end{tabular}

Table 3: Statistical comparison of depend and independent variables of $S$. richardsonii

\begin{tabular}{|l|l|l|l|l|l|l|}
\hline $\begin{array}{l}\text { Dependent } \\
\text { Variable (Y) }\end{array}$ & $\begin{array}{l}\text { Independent } \\
\text { variable (x) }\end{array}$ & $\begin{array}{l}\text { Equation } \\
\text { Log Y=Log } \mathbf{a}+\mathbf{b} \log \mathbf{x}\end{array}$ & $\begin{array}{l}\text { Regression } \\
\text { Coefficient } \\
\text { (b) }\end{array}$ & $\begin{array}{l}\text { Correlation } \\
\text { Coefficient } \\
\text { (r) }\end{array}$ & $\begin{array}{l}\text { ANOV } \\
\text { A } \\
\text { F-value }\end{array}$ & p-value \\
\hline Fecundity (F) & $\begin{array}{l}\text { Total length of } \\
\text { fish (TL) }\end{array}$ & Log F $=2.9942+2.5709 \log$ TL & 2.570 & 0.940 & 85.96 & $<0.05$ \\
\hline Fecundity (F) & $\begin{array}{l}\text { Total body } \\
\text { weight (FW) }\end{array}$ & Log F $=0.840+1.0323 \log$ FW & 1.0323 & 0.937 & 122.49 & $<0.005$ \\
\hline Fecundity (F) & $\begin{array}{l}\text { Weight of } \\
\text { Ovary (OW) }\end{array}$ & Log F $=2.4545+0.699 \log$ OW & 0.6966 & 0.8526 & 21.76 & $<0.118$ \\
\hline Fecundity (F) & $\begin{array}{l}\text { Volume of } \\
\text { Ovary (OV) }\end{array}$ & Log F $=2.229+0.813 \log$ OV & 0.813 & 0.9134 & 39.53 & $<0.005$ \\
\hline Fecundity (F) & $\begin{array}{l}\text { Length of } \\
\text { ovary (OL) }\end{array}$ & Log F $=1.9299+0.7867 \log$ OL & 0.7867 & 0.56884 & 22.33 & $? ? ?$ \\
\hline $\begin{array}{l}\text { Wt. of Ovary } \\
\text { (OW) }\end{array}$ & $\begin{array}{l}\text { Total length of } \\
\text { fish (FL) }\end{array}$ & Log F $=-6.5726+3.2145 \log$ FL & 3.2145 & 0.8251 & 16.83 & $<0.005$ \\
\hline $\begin{array}{l}\text { Wt. of Ovary } \\
\text { (OW) }\end{array}$ & $\begin{array}{l}\text { Total weight } \\
\text { of fish (FW) }\end{array}$ & Log F $=-2.4870+0.008 \log$ FW & 0.0082 & 0.868154 & 21.62 & $<0.005$ \\
\hline
\end{tabular}




\section{Thapliyal et al.}

of new generation and this estimate is the starting point of many production and population studies. The eggs laid by the female are a link between generations. Populations of fishes appear to adopt as per the environmental condition through food supply and so it is one of the basic means of adjusting the rate of reproduction to changing conditions (Nikolsky, 1969). Fecundity of Tor (Pathani, 1981, in Kumaon region and Nautiyal and Lal, 1985, in Garhwal region) and Schizothorax plagistomas (Agarwal et al., 1988) has been investigated earlier. In the present study, fecundity of Schizothorax richardsonii was investigated and it ranged from minimum of 3007 / 3128 to a maximum of 13649 to 13851 whereas the total average fish length ranged from $384 \mathrm{~mm}$ to 544 $\mathrm{mm}$.

The fecundity of fishes is often correlated with the total length of fish, weight, and age of fish along with the length, weight and volume of the ovary also. In the present study, it was observed that the fecundity increased at the rate of 2.57 times of the length of fish. In S. plagiostomus, it was found that the fecundity rate increased at rate of 2.29 times of the length (Agarwal et al., 1988). A similar high exponential value of fecundity to fish length of 2.36 in S. richardsonii (Misra, 1982) and 2.68 in S. niger (Joyti and Malhotra, 1972) were also recorded earlier. A linear correlation was also observed in case of fecundity versus ovary volume where as other parameter did not so a liner correlation.

However the most important highlight of this study is the comparison of present data set of 1996 to 1998 to the data of 2016 to 2019 for Schizothorax species in same region. Singh et al., (2016), have worked on fecundity of Schizothorax sp. (plagiostomous) at the exact same location and have published their results. They report that "the number of ripe ova was found to vary from 3206 to 33611 in fish ranging in total lengths $23.4 \mathrm{~cm}$ to $46.6 \mathrm{~cm}$, body weight between $150 \mathrm{~g}$ and $2050 \mathrm{~g}$, ovary length from $8.8 \mathrm{~cm}$ to $22.6 \mathrm{~cm}$ and ovary weight ranging from $11.4 \mathrm{~g}$ to $122.4 \mathrm{~g}$. Fecundity was related to the total length of fish, body weight and total ovary length and weight using regression equations" (quoted verbatim). These values are even towards the higher sides from the earlier values and are indicative that the population of Schizothorax $s p$ has sustained the fecundity despite anthropogenic pressures. It has been reported that anthropogenic pressures and urbanization might drive evolution process in fishes (Kern and Langerhans, 2018; Oke et al., 2017). This is unique adaptive skill of the Schizothorax $s p$ as it has survived through the evolutionary age of Himalaya. We hypothesize that the population of Schizothorax species can sustain its population after anthropogenic damage to its breeding grounds if the habitat conditions improve after 15 to 20 years. Hence, this unique adaptive skill can be used as a conservation strategy for all the areas of Garhwal Himalaya where anthropogenic activity is disturbing the aquatic habitat.

\section{Acknowledgement}

The present work is from the thesis of Dr. Madhu Thapliyal that was carried out at Department of Zoology and Biotechnology at HNB Garhwal University, Srinagar Garhwal under the guidance of Dr. S. N. Bahuguna.

\section{Conclusion}

Schizothorax sp. is the most abundant fish species that is found in all the fresh water systems of Uttarakhand and comprises of major portion of fish catch. This is one of the most accepted food fish and is sold extensively all over Uttarakhand but the commercial market is totally unorganized. Present research suggests that Schizothorax sp. can adaptive very well to long term pressures of urbanization and anthropogenic activities and sustain its populations. Thus this species has a potential to become a very good commercial model for the local population. This is also important keeping in view that in the mountainous terrain of Uttarakhand there are no industrial setup as such and fisheries based on Schizothorax sp. can be developed well with technical inputs and can eventually impact the socio-economic condition of locals.

\section{References}

Agarwal, N. K. and Singh, H. 2009. Snow trout fishery in Garhwal Himalaya: causes of depletion and strategy for propagation. Environment Conservation Journal, 10(1-2): 141-146.

Agarwal, N. K., Singh W. and Singh, H. R. 1988. Fecundity of the snow-trout, Schizothorax plagiostomus (Heckel) from Garhwal Himalaya. Journal of the Indian Fisheries Association, 18: 537-548. 
Bisht, J. S. and Joshi, M. L. 1975. Seasonal histological changes in the ovaries of a mountain stream teleost Schizothorax richardsonii (Gray and Hard). Cells Tissues Organs, 93(4): 512-525.

Gandotra, R., Shanker, R. and Singh, D. 2009. Studies on fecundity of snow trout Schizothorax richardsonii (Gray) from the lotic bodies of Rajouri district (J\&K). Current World Environment, 4(1): 127-132.

Jan, M., Jan, U. and Shah, G. M. 2014. Studies on fecundity and Gonadosomatic index of Schizothorax plagiostomus (Cypriniformes: Cyprinidae). Journal of Threatened Taxa, 6(1): 5375-5379.

Jyoti, M. K. and Malhotra, Y. R. 1972. Studies on fecundity schizothorax niger (heckel) from Dal lake Kashmir. Journal of Experimental Biology, 10: 74-75.

Kandler, R. and Pirwitz, W. 1957. Uber die fruch barkeit der platt fische in Nordses-Ostee Raum. Kieler Meeresfrosch 13(1): 11-34.

Kern, E. M. and Langerhans, R. B. 2018. Urbanization drives contemporary evolution in stream fish. Global Change Biology. DOI: 10.1111/gcb.14115

Madhu, T., Bahuguna, S. N., Tribhuwan, C. and Ashish, T. 2012. Induced breeding of snowtrout (Schizothorax richardsonii-Gray), from Garhwal Himalaya (Uttarakhand, India) by pituitary gland extract. Environment Conservation Journal, 13(1-2): 23-29.

Nautiyal, P. and Lal, M. S. 1985. Fecundity of the Garhwal Himalayan mahseer Tor putitora(Ham.). J. Bombay Nat. Hist. Soc. 82(2): 253-257.

Nikolsky, G.V. 1969. Theory of Fish Population Dynamics. Otto Science Publishers, Koenigstein: 317.

Oke, K. B., Rolshausen, G., LeBlond, C. and Hendry, A. P. 2017. How parallel is parallel evolution? A comparative analysis in fishes. The American Naturalist, 190(1): 1-16. https://doi.org/10.1086/691989.

Pathani, S. S. 1981. Fecundity of mahseer Tor putitora (Ham.); Proc. Indian Acad. Sci. (Anim. Sci.) 90: 253-260.

Qadri, M. Y., Mir, S. and Yousuf, A. R. 2013. Breeding biology of Schizothorax richardsonii gray and hard. Journal of the Indian Institute of Science, 64(6): 73.
Roopma, G., Ravi, S. and Dalvinder, S. 2009. Studies on fecundity of snow trout Schizothorax richardsonii (Gray) from the lotic bodies of Rajouri district (J\&K). Current World Environment, 4(1): 127-132.

Roy, N. K., Raymajhi, A., Pradhan, N. and Wagle, S. K. 2011. Reproductive performance of domesticated asala (schizothorax richardsonii) in captive environment at godawari, lalitpur. (eds.): 100.

Sabha, K. K., Najar, A. M., Bhat, F. A., Shah, T. H., Balkhi, M. H. and Faisal, R. 2017. Reproductive biology of (Schizothorax niger) snow trout in Nigeen Lake Kashmir. Journal of Experimental Zoology, India, 20(1): 623-626.

Sharma, A. K. and Bargali, H. 2018. Food and feeding habits of Schizothorox Richordsonii (Gray, 1832) Inhibiting Bhagirathi River, Tehri Garhwal, India.

Singh, D. and Sharma, R. C. 1995. Age and growth of a Himalayan teleost Schizothorax richardsonii (Gray) from the Garhwal Hills (India). Fisheries research, 24(4): 321329.

Singh, Y., Dewan, S. and Bhatt, J. P. 2016. Ascertaining spawning behavior of a Himalayan trout, Schizothorax plagiostomus using combinatorial approach. Int. J. Res. Fish. Aquacul, 6: 39-46.

Simpson, A. C. 1959. The spawning of plaice in the North Sea. Fish. Invest. Lond. Ser., 2, 1-111.

Sunder, S. and Subla, B. A. 2013. On the fecundity of Schizothorax curvifrons Heckel from River Jhelum, Kashmir. Journal of the Indian Institute of Science, 65(3): 31.

Thapliyal, M., Bahuguna, S. N. and Thapliyal, A. 2011. Egg and early larval development of snow trout, Schizothorax richardsonii (Cyprinidae), an important food fish of Garhwal Himalaya, Uttarakhand, India. J. of Mountain Research. 5:1-8.

Thapliyal, M., Bahuguna, S. N., Chandra, T. and Thapliyal, A. 2012. An account of ova maturation and Gonado-Somatic Index (GSI) of snow trout, Schizothorax richardsonii (Gray) of Garhwal Himalaya. Journal of Environment and Biosciences. 26 (2): 43-50.

Wagle, S. K. 2015. Studies on gonadosomatic index, fecundity and hatchability of domesticated stock of asala Schizothorax richardsonii (Gray) from Nallu River of Lalitpur District. Our Nature, 12(1): 19-27. 